\title{
Studi Perbandingan Gedung dengan Iregularitas Horizontal Menggunakan Base Isolation dan Fixed Base
}

\section{Comparative Study of a Horizontally Irregular Building with Base Isolation and Fixed Base}

\author{
Marcellino Arifin ${ }^{1, a)}$, Lidya Fransisca ${ }^{2, b)}$ \& Altho Sagara ${ }^{2, c)}$ \\ ${ }^{1)}$ Mahasiswa, Jurusan Teknik Sipil, Universitas Katolik Parahyangan. \\ ${ }^{2}$ Dosen, Jurusan Teknik Sipil, Universitas Katolik Parahyangan.
}

Koresponden : ${ }^{a)}$ arifin.marcellino04@gmail.com, ${ }^{b}$ lidyafransiscatjong@gmail.com \& c)altho_sagara@hotmail.com

\begin{abstract}
ABSTRAK
Jumlah penduduk yang terus bertambah menyebabkan peningkatan kebutuhan penduduk, salah satunya yaitu rumah tinggal ataupun bangunan dengan fungsi lainnya. Adanya keterbatasan lahan mengakibatkan pembangunan gedung bertingkat semakin berkembang. Dalam mendesain, selain beban gravitasi, tentunya suatu gedung harus mampu menahan beban lateral akibat gempa bumi. Dewasa ini, dilakukan suatu pendekatan untuk mengurangi gaya lateral dengan menggunakan base isolation. Prinsipnya adalah memisahkan struktur bangunan dengan tanah sehingga ketika gempa terjadi, tanah akan tetap mengalami pergerakan tetapi struktur bangunan akan tetap mempertahankan posisinya. Pada penelitian ini, dilakukan analisis perbandingan gedung yang menggunakan base isolation (khususnya lead rubber bearing) dan fixed base. Berdasarkan analisis respons spektrum, penggunaan base isolation dapat mereduksi gaya geser dasar pada gedung, tetapi menyebabkan gedung menjadi lebih fleksibel pada arah horizontal sehingga gedung memiliki periode dan perpindahan lantai yang lebih besar. Kekakuan horizontal dan kekakuan vertikal yang dimiliki base isolation tidak mampu menahan momen pada dasar gedung sehingga terjadi distribusi momen ke tingkat diatasnya dan meningkatkan kebutuhan tulangan longitudinal balok induk. Berbeda halnya dengan kolom, penggunaan base isolation meningatkan kekuatan kolom sehingga dimensi dapat diperkecil dan kebutuhan tulangan longitudinal berkurang. Berdasarkan analisis riwayat waktu, penggunaan base isolation meningkatkan kekuatan elemen struktur sehingga tidak terjadi sendi plastis pada kolom serta meningkatkan tingkat kinerja struktur.
\end{abstract}

Kata Kunci : manajemen aset infrastruktur \& fasilitas, perancangan, base isolation, analisis respons spektrum, analisis riwayat waktu

\section{PENDAHULUAN}

Dewasa ini, Indonesia sering kali dilanda bencana alam yang salah satunya adalah gempa bumi. Menurut Badan Meteorologi, Klimatologi, dan Geofisika, Indonesia merupakan negara di mana tiga pelat tektonik bertemu (Eurasia, Australia, dan Pasifik) yang menyebabkan banyaknya aktivitas seismik yang terasa hingga permukaan tanah.

Di sisi lain, kebutuhan akan infrastruktur di Indonesia semakin tinggi. Hal ini didukung oleh faktor pertumbuhan penduduk. Berdasarkan Badan Perencanaan Pembangunan Nasional jumlah penduduk dari tahun 2018 sampai dengan Januari 2019 meningkat sebanyak dua juta penduduk. Dapat dilihat dari data tersebut, seiring dengan pertumbuhan penduduk 
menyebabkan meningkatnya permintaan akan kebutuhan masyarakat namun tidak sebanding dengan ketersediaan lahan yang ada di Indonesia. Untuk mengatasi masalah tersebut, maka dibangunlah gedung bertingkat tinggi. Akan tetapi, banyaknya gedung bertingkat terkadang menimbulkan masalah yang baru yaitu kerusakan bangunan yang terjadi akibat bencana alam, salah satunya gempa bumi.

Berdasarkan prinsip Manajemen Aset Infrastruktur dan Fasilitas, bangunan gedung harus dirancang sedemikian rupa sehingga pengoperasian bisa berjalan dengan selamat, ekonomis, efektif dan efisien. Dalam bangunan gedung didalamnya terdapat komponen infrastruktur dan komponen fasilitasnya (Soemitro \& Suprayitno 2018; Suprayitno \& Soemitro 2018). Salah satu aspek keselamatan yang harus diperhatikan untuk Bangunan Gedung di Indonesia adalah keselamatan terhadap gempa bumi (UU 28/02).

Seiring dengan perkembangan teknologi dalam merencanakan bangunan tahan gempa, telah dikembangkan suatu pendekatan alternatif untuk mengurangi risiko kerusakan pada bangunan yaitu dengan cara mereduksi gaya gempa yang terjadi. Salah satu konsep perencanaan yang telah digunakan yaitu dengan menggunakan base isolaton. Beberapa tipe base isolation diantaranya; roller and ball bearing, spring isolator, sliding bearing, dan elastomeric rubber bearing. Pada peneitian ini akan dibahas lebih lanjut mengenai elastomeric rubber bearing khususnya lead rubber bearing. Tujuan dari penelitian ini adalah melakukan analisis dan mendesain ulang komponen struktur pada gedung bertingkat yang menggunakan base isolation dengan iregularitas horizontal serta membandingkan kinerja struktur gedung yang menggunakan base isolation dan fixed base.

\section{STUDI PUSTAKA}

Dalam menghadapi bencana alam seperti gempa bumi, biasanya suatu gedung di desain secara konvensional yaitu dengan menambah kapasitas daya tahan pada suatu struktur seperti penggunaan dinding geser (shear wall) dan bresing (bracing). Akan tetapi, cara konvensional tersebut mampu memberikan dampak pada komponen non-struktural. Maka dari itu, diciptakan suatu pendekatan alternatif berupa sistem peredam yang digunakan untuk mengantisipasi kerusakan yang terjadi pada sebuah bangunan dan komponen di dalamnya yang mengalami getaran yang terasa sampai permukaan tanah akibat gempa bumi. Sistem tersebut adalah penggunaan base isolation. Base isolation memiliki prinsip memisahkan struktur bangunan dengan tanah sehingga ketika gempa terjadi, tanah akan tetap mengalami pergerakan tetapi struktur bangunan akan tetap mempertahankan posisinya.

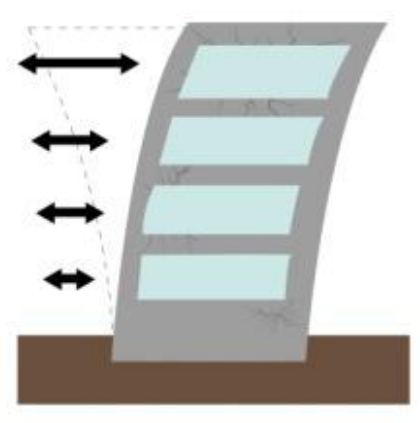

CONVENTIONAL STRUCTURE

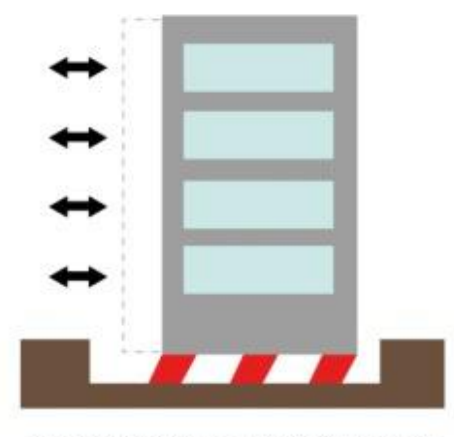

SEISMIC ISOLATED STRUCTURE

Gambar 1. Cara Kerja Base Isolation (sumber: http://did.org.tr)

Elastomeric bearing tersusun atas lapisan karet dan pelat baja secara bergantian. Lapisan karet memiliki ketebalan 8 - $20 \mathrm{~mm}$ dan dipisahkan oleh pelat baja dengan tebal $2-3$ $\mathrm{mm}$. Adanya pelat baja bertujuan untuk mengurangi deformasi vertikal pada sistem serta menopang beban vertikal. Akan tetapi pelat baja tidak mempengaruhi pergerakan secara 
horizontal sehingga lapisan karet akan tetap fleksibel. Secara umum, elastomeric bearing yang menggunakan karet alami maupun sintetis hanya mampu menahan $2-3 \%$ dari redaman kritis sehingga mampu menyebabkan perpindahan yang besar. Oleh karena itu, untuk diaplikasikan pada suatu struktur yang lebih kompleks dan jembatan digunakan senyawaelastomer khusus yang dikenal dengan High Damping Rubber Bearing (HDRB) atau kombinasi dengan perangkat lainnya yang dikenal dengan Lead Rubber Bearing (LRB).

LRB merupakan bagian dari elastomeric rubber bearing yang di dalamnya terdapat penambahan perangkat berupa inti yang terbuat dari timah (lead core). Adanya inti tersebut membuat sistem isolasi ini mejadi lebih kaku dan mampu menahan beban vertikal maupun lateral dan memiliki disipasi energi yang tinggi terhadap beban lateral. Intinya adalah LRB menggabungkan fungsi kekakuan pada saat mengalami beban secara vertikal dan fleksibilitas pada saat mengalami beban lateral. Dengan kata lain, sistem isolasi ini mampu diaplikasikan secara tunggal dan efektif pada daerah dengan seismik yang tinggi.

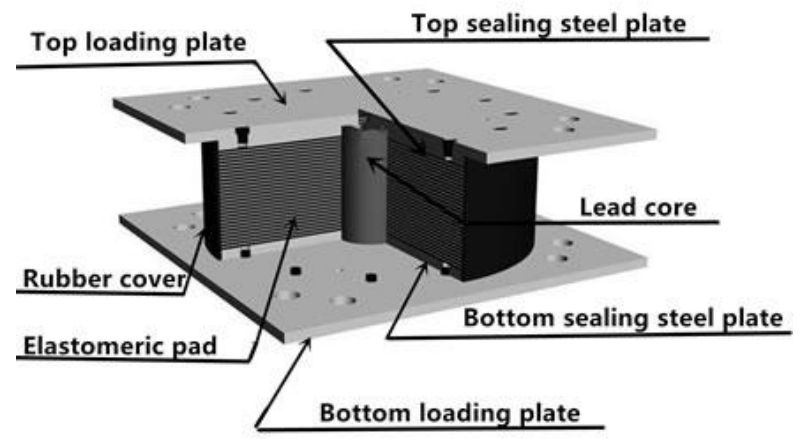

Gambar 2. Lead Rubber Bearing (sumber: https://www.bridgebearing.org)

Beberapa contoh penerapan LRB adalah Bihar's Police Station, Patna, India; USC Hospital University, California, Amerika Serikat; dan William Clayton Building, Wellington, Selandia Baru.

Pemodelan LRB dilakukan dengan menggunakan parameter-parameter sebagai berikut :

Moment of Inertia

$\mathrm{I}=\frac{\pi \mathrm{B}^{4}}{64}$

Keterangan:

$\mathrm{B} \quad=$ rubber diameter

Vertical Stiffness

$\mathrm{K}_{\mathrm{v}}=\frac{\mathrm{E}_{\mathrm{c}} \mathrm{A}_{\mathrm{LRB}}}{\mathrm{t}_{\mathrm{r}}}$

Keterangan:

$\mathrm{E}_{\mathrm{c}} \quad=$ compression modulus

$\mathrm{A}_{\mathrm{LRB}}=$ area of bearing

$\mathrm{t}_{\mathrm{r}} \quad=$ total thickness of rubber

Post Yield Stiffness

$\mathrm{K}_{\mathrm{u}}=\frac{\mathrm{K}_{\mathrm{d}}}{\mathrm{n}}$

Keterangan:

$\mathrm{K}_{\mathrm{d}} \quad=$ pre yield in rubber

$\mathrm{n} \quad=$ post yield stiffness to pre yield stiffness ratio of rubber

Horizontal Stiffness 
$\mathrm{K}_{\mathrm{H}}=\frac{\mathrm{GA}_{\mathrm{LRB}}}{t_{r}}$

Keterangan:

$$
\begin{array}{ll}
\mathrm{G} & =\text { shear modulus } \\
\mathrm{t}_{\mathrm{r}} & =\text { total thickness of rubber }
\end{array}
$$

Yield Displacement

$\mathrm{D}_{\mathrm{y}}=\frac{\mathrm{Q}_{\mathrm{do}}}{\mathrm{K}_{\mathrm{u}}-\mathrm{K}_{\mathrm{d}}}$

Keterangan:

$\mathrm{Q}_{\mathrm{do}} \quad=$ force at design displacement

$\mathrm{K}_{\mathrm{u}} \quad=$ post yield in rubber

$\mathrm{K}_{\mathrm{d}} \quad=$ pre yield in rubber

Yield Strength

$\mathrm{F}_{\mathrm{y}}=\mathrm{Q}_{\mathrm{do}}+\mathrm{K}_{\mathrm{d}} \mathrm{D}_{\mathrm{y}}$

Keterangan:

$\mathrm{Q}_{\mathrm{do}}=$ force at design displacement

$\mathrm{D}_{\mathrm{y}} \quad=$ yield displacement

$\mathrm{K}_{\mathrm{d}} \quad=$ pre yield in rubber

\section{METODE PENELITIAN}

Berikut adalah tahapan yang merupakan sebuah pendekatan yang dilakukan untuk menjawab tujuan dari penelitian ini:

1. Preliminary Design

Perancangan awal berupa data gedung beserta dimensi elemen struktur yaitu; kolom, balok dan pelat.

Data Gedung

- Material gedung $\quad$ : Beton Bertulang

- Fungsi gedung : Perkantoran

- Jumlah lantai : 10 lantai

- Tinggi antar-lantai $\quad: 3.2 \mathrm{~m}$

- Lokasi : Mataram

- Kelas situs : SD (tanah sedang)

- Kategori desain seismik : D

- Sistem struktur : : Rangka Beton Bertulang Pemikul Momen Khusus

- Mutu beton : $30 \mathrm{MPa}$

- Tegangan leleh tulangan : $400 \mathrm{MPa}$ Dimensi Elemen Struktur

- Kolom (lantai 1-5): $600 \times 600 \mathrm{~mm}^{2}, 800 \times 800 \mathrm{~mm}^{2}$ dan $800 \times 1400 \mathrm{~mm}^{2}$

- Kolom (lantai 6-10): 600 x $600 \mathrm{~mm}^{2}$ dan $700 \times 1200 \mathrm{~mm}^{2}$

- Balok induk: $350 \times 700 \mathrm{~mm}^{2}$

- Balok anak: 200 x $400 \mathrm{~mm}^{2}$

- Pelat: $120 \mathrm{~mm}$

2. Pemodelan Gedung

Terdapat dua buah gedung yang mempunyai bentuk geometri yang sama, akan tetapi terdapat perbedaan pada bagian dasar struktur. Model pertama menggunakan base 
isolation dan model kedua adalah fixed base. Kedua gedung diberikan beban gravitasi (sesuai SNI 1727:2013) dan beban gempa (SNI 1726:2012) yang sama.

3. Spesifikasi Base Isolation

Jenis yang digunakan adalah lead rubber bearing yang di desain berdasarkan UBC 2000.

Tabel 1. Spesifikasi Base Isolation

\begin{tabular}{lcc}
\hline & LRB 1 (internal) & LRB 2 (eksternal) \\
\hline Axial Load Capacity $(\mathrm{kN})$ & 7600 & 4000 \\
\hline Momen Inertia $\left(\mathrm{m}^{4}\right)$ & 0.49 & 0.02 \\
\hline Effective Damping & 0.05 & 0.05 \\
\hline U1 Effective Stiffness $(\mathrm{kN} / \mathrm{m})$ & 2097978.809 & 1343232.518 \\
\hline $\mathrm{U} 2$ \& U3 Effective Stiffness $(\mathrm{kN} / \mathrm{m})$ & 3077.861 & 1970.603 \\
\hline $\mathrm{U} 2$ \& U3 Stiffness $(\mathrm{kN} / \mathrm{m})$ & 38189.255 & 23578.747 \\
\hline $\mathrm{U} 2$ \& U3 Distance from End-J $(\mathrm{m})$ & 0.0025 & 0.0025 \\
\hline $\mathrm{U} 2$ \& U3 Yield Strength $(\mathrm{kN})$ & 104.617 & 69.535 \\
\hline
\end{tabular}

4. Analisis

Analisis yang digunakan yaitu analisis respons spektrum dan analisis riwayat waktu dengan menggunakan perangkat lunak. Pada analisis respons spektrum perilaku struktur yang ditinjau yaitu simpangan lantai dan gaya geser tiap lantai. Sedangkan pada analisis riwayat waktu, tingkat kinerja struktur merupakan hasil akhir yang akan ditinjau.

\section{ANALISIS PENELITIAN}

Pada bagian ini, gedung dengan fixed base selanjutnya akan disebut sebagai model 1, sedangkan untuk gedung yang menggunakan base isolation selanjutnya akan disebut sebagai model 2.

Berikut adalah Gambar 3, Gambar 4 dan Gambar 5 yang masing-masing menunjukkan model gedung tiga dimensi, jenis perletakan model 1 dan jenis perletakan model 2 .

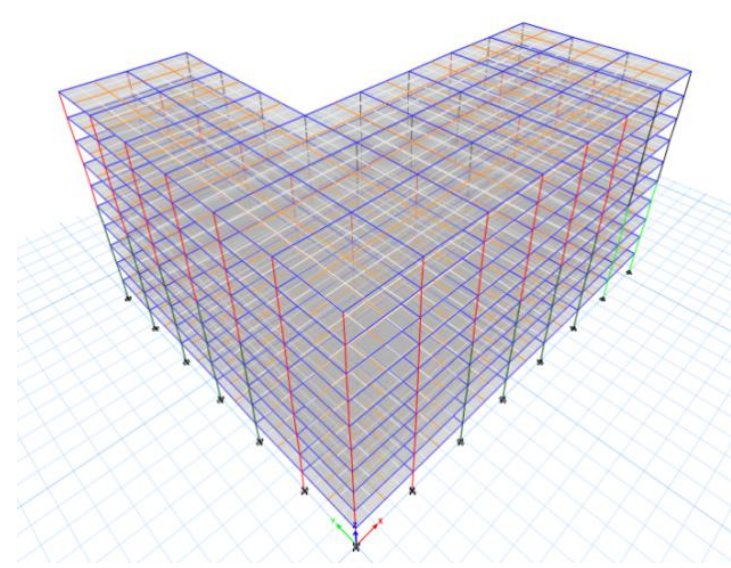

Gambar 3. Model Gedung Tiga Dimensi 


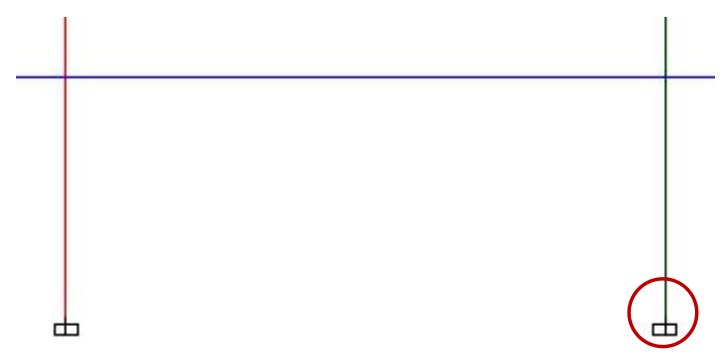

Gambar 4. Jenis Perletakan Model 1

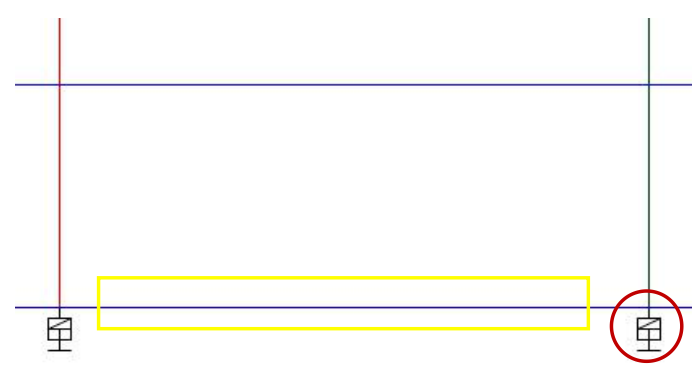

Gambar 5. Jenis Perletakan Model 2

Pada model 2, terdapat balok pengikat di bagian dasar struktur. Hal tersebut diperlukan karena penggunaan base isolation memisahkan kolom dengan pondasi sehingga memungkinkan terjadinya pergerakan kolom yang tidak seragam. Sebelum dilakukan analisis pemeriksaan dilakukan terhadap gerak dominan gedung yang terlampir pada Tabel 2 dan Tabel 3.

Tabel 2.Gerak Dominan Gedung Model 1

\begin{tabular}{cccc}
\hline Mode & UX & UY & UZ \\
\hline 1 & $6,01 \mathrm{E}-03$ & 0.7446 & $2,94 \mathrm{E}-02$ \\
\hline 2 & 0.7407 & $9,45 \mathrm{E}-03$ & 0.0012 \\
\hline
\end{tabular}

Tabel 3.Gerak Dominan Gedung Model 2

\begin{tabular}{cccc}
\hline Mode & UX & UY & UZ \\
\hline 1 & 0.0001 & 0.942 & 0.0035 \\
\hline 2 & 0.9471 & 0.0001 & $2,35 \mathrm{E}-03$ \\
\hline
\end{tabular}

Kedua model gedung memiliki gerak dominan yang sama. Untuk mode 1 dan 2 masingmasing terhadap arah y dan arah $\mathrm{x}$. Hasil tersebut diperoleh melalui pendekatan berupa penempatan pusat massa dan pusat kekakuan berada di satu titik pada model gedung sehingga tidak terjadi puntir karena untuk dua mode pertama diharapkan terjadinya gerak translasi. Untuk model 1 periode getar arah $\mathrm{x}$ dan arah y masing-masing 1.814 detik dan 1.86 detik dengan ragam getar mencapai lebih dari $90 \%$ terdapat pada mode 21 . Sedangkan untuk model 2, periode getar arah $\mathrm{x}$ dan arah y masing-masing 2.973 detik dan 2.999 detik dengan ragam getar mencapai lebih dari $90 \%$ terdapat pada mode 4 .

\section{Ketidakberaturan Horizontal}

Model gedung yang berbentuk L dengan jarak antar kolom $8 \mathrm{~m}$, memiliki daerah terbuka sehingga perlu dilakukan pengecekan terhadap ketidakberaturan sudut dalam. Setelah dilakukan analisis, dapat disimpulkan bahwa terjadi ketidakberaturan sudut dalam karena 
daerah terbuka pada arah $\mathrm{x}$ dan arah y memiliki panjang yang melebihi $15 \%$ panjang total pada setiap arahnya. Adanya ketidakberaturan horizontal tipe 2 dan memiliki kateogori desain seismik D, maka diperlukan peningkatan gaya $25 \%$ pada sambungan antar diafragma dengan elemen vertikal dan dengan elemen kolektor.

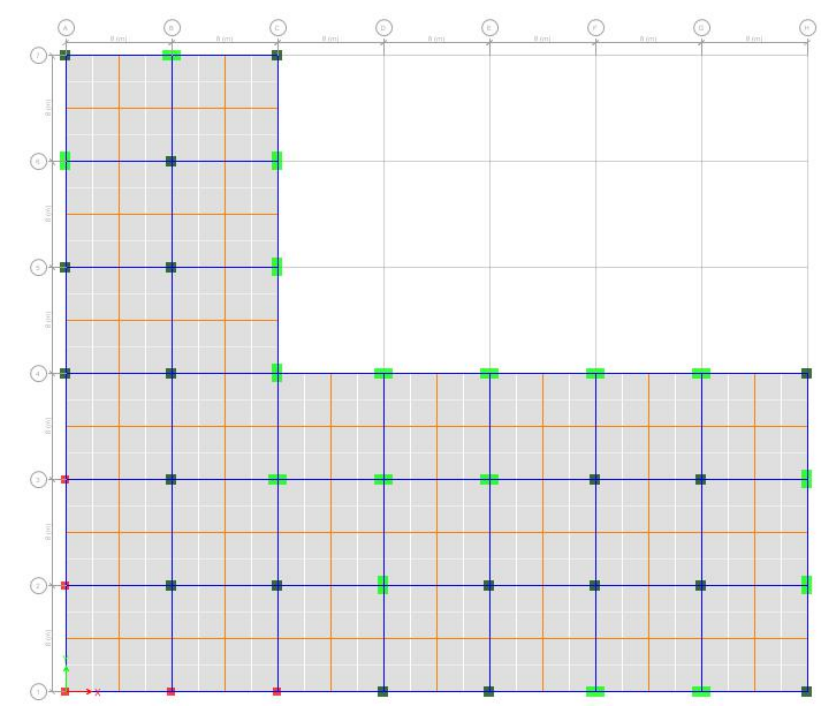

Gambar 6. Denah Model Gedung

Tabel 4.Pemeriksaan Ketidakberaturan Sudut Dalam Arah X

\begin{tabular}{crc}
\hline Px & 40 & $\mathrm{~m}$ \\
\hline $\mathbf{L x}$ & 56 & $\mathrm{~m}$ \\
\hline $\mathbf{0 . 1 5} \mathbf{~ L x}$ & 8.4 & $\mathrm{~m}$ \\
\hline \multicolumn{3}{c}{ Px $>\mathbf{0 . 1 5}$} \\
$\mathbf{L r}$
\end{tabular}

Tabel 5 . Pemeriksaan Ketidakberaturan Sudut Dalam Arah Y

\begin{tabular}{crc}
\hline Py & 24 & $\mathrm{~m}$ \\
\hline Ly & 48 & $\mathrm{~m}$ \\
\hline 0.15 Ly & 7.2 & $\mathrm{~m}$ \\
\hline \multicolumn{2}{c}{ Py $>$ 0.15 Ly } \\
\hline
\end{tabular}

\section{Simpangan Lantai - Gaya Geser Tiap Lantai}

Dilakukan analisis respons spektrum pada kedua model gedung dengan tinjauan; simpangan lantai dan gaya geser tiap lantai. Pada model 2, gaya lateral bekerja pada base isolation pada saat terjadi gempa bumi. Hal tersebut mengakibatkan simpangan lantai pada model 2 menjadi lebih besar karena base isolation membuat struktur menjadi lebih fleksibel terhadap arah horizontal. Selain itu, adanya disipasi energi yang dimiliki base isolation menghasilkan reduksi gaya tiap lantai pada struktur sebesar $33.2 \%$ pada arah $\mathrm{x}$ dan $32.8 \%$ pada arah y untuk gaya geser dasar. 


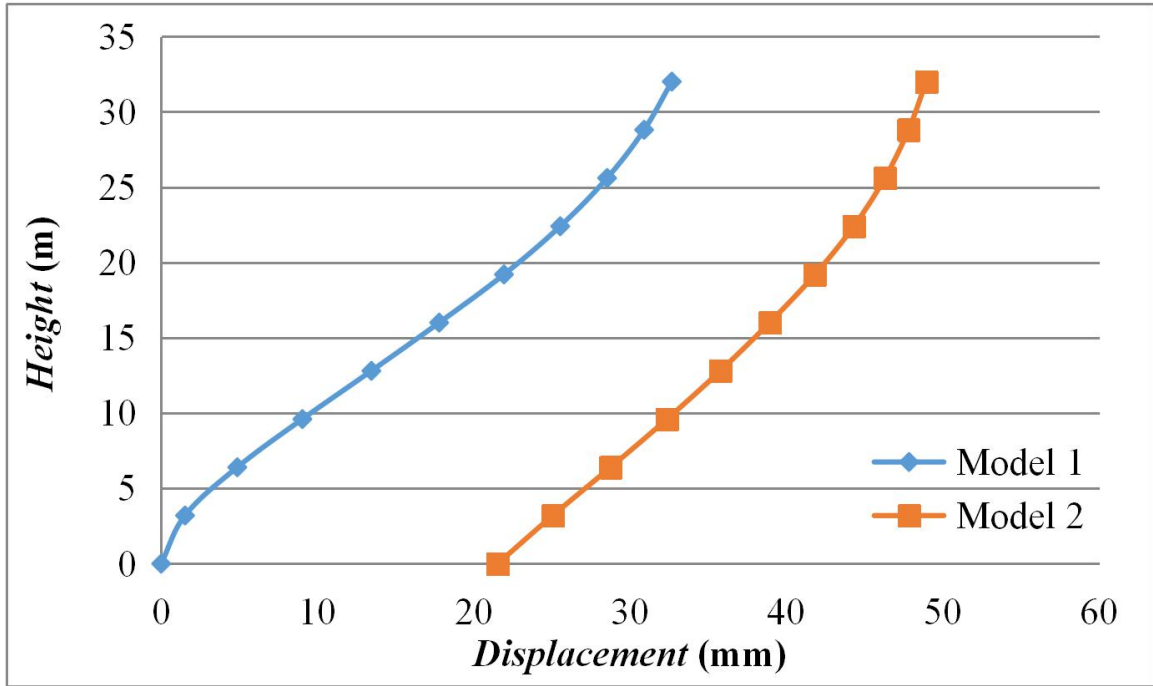

Gambar 7. Perbandingan Simpangan Lantai Arah X

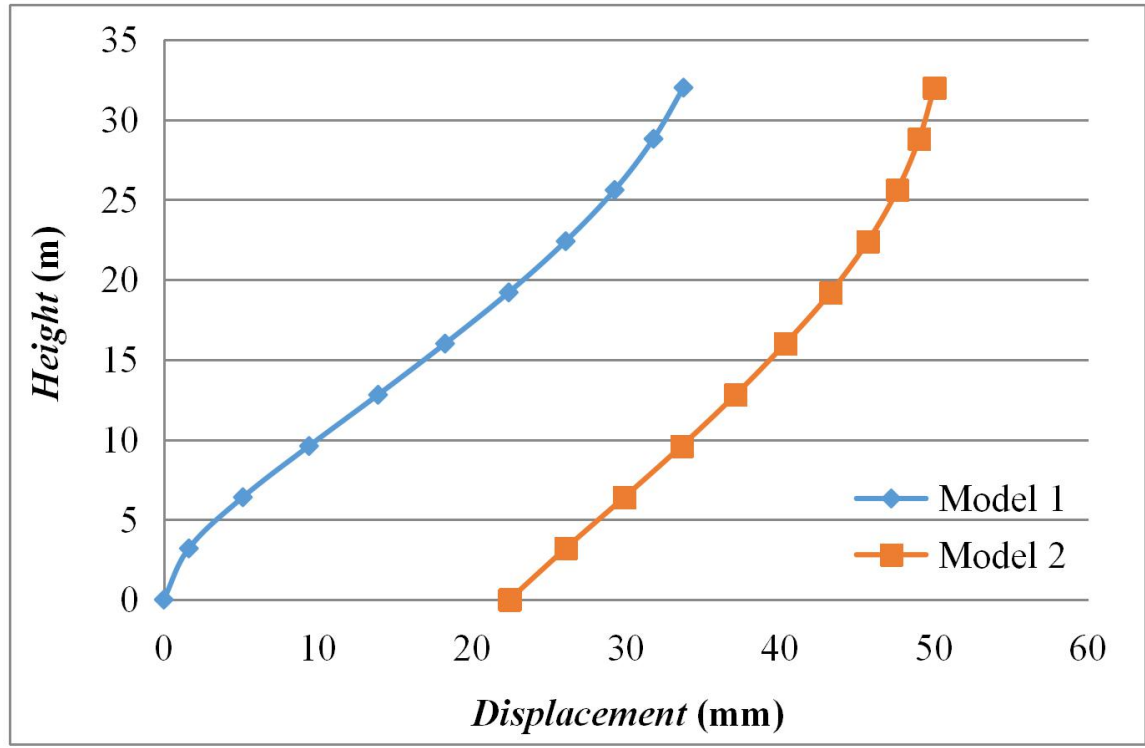

Gambar 8. Perbandingan Simpangan Lantai Arah Y

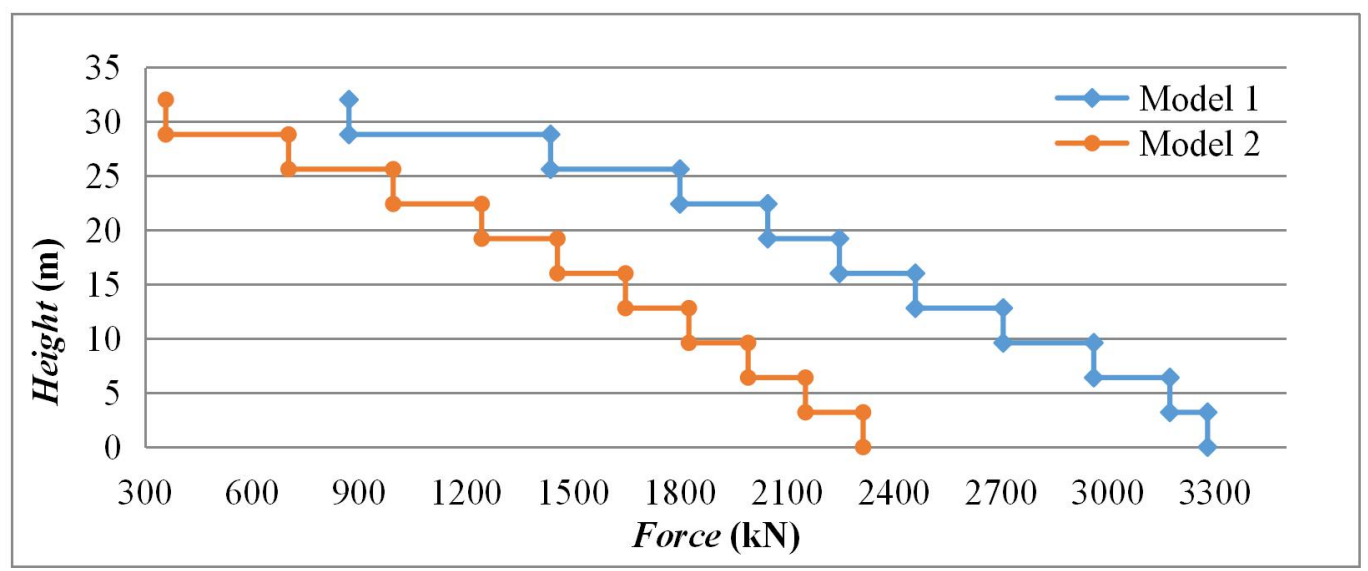

Gambar 9. Perbandingan Gaya Geser Tiap Lantai Arah X 


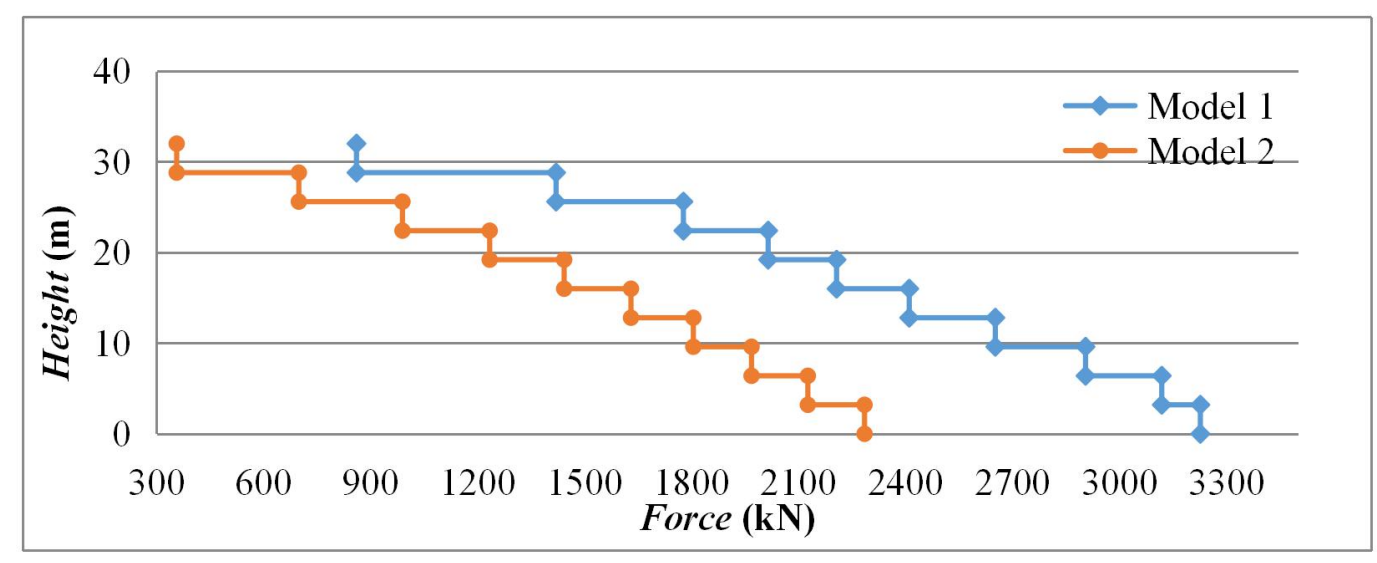

Gambar 10. Perbandingan Gaya Geser Tiap Lantai Arah X

\section{Pengaruh Base Isolation Terhadap Elemen Struktur}

Elemen struktur yang akan dibahas pada penelitian ini adalah balok induk dan kolom. Pada balok induk, yang akan ditinjau adalah kebutuhan tulangan longitudinal. Sedangkan pada kolom, yang akan ditinjau adalah kebutuhan dimensi dan tulangan longitudinal.

Setelah dilakukan analisis, terjadi peningkatan kebutuhan tulangan longitudinal balok pada model 2 sebesar $3.2 \%$. Hal tersebut dapat terjadi karena;

- $\quad$ Seiringan dengan bertambahnya jumlah balok pada model 2, khususnya pada lantai dasar sebagai pengaikat antar kolom yang terpisah dengan pondasi, maka bertambah juga kebutuhan tulangan longitudinal balok secara keseluruhan.

- Kekakuan horizontal dan vertikal yang dimiliki base isolation tidak mampu menahan momen lentur dasar struktur sehingga terjadi distribusi momen ke tingkat diatasnya.

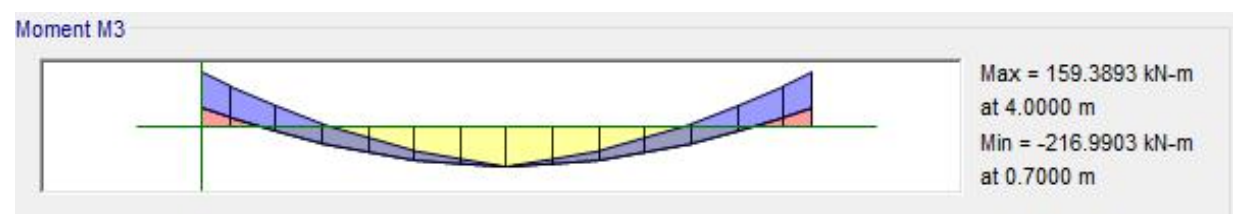

Gambar 11. Diagram Momen Model 1

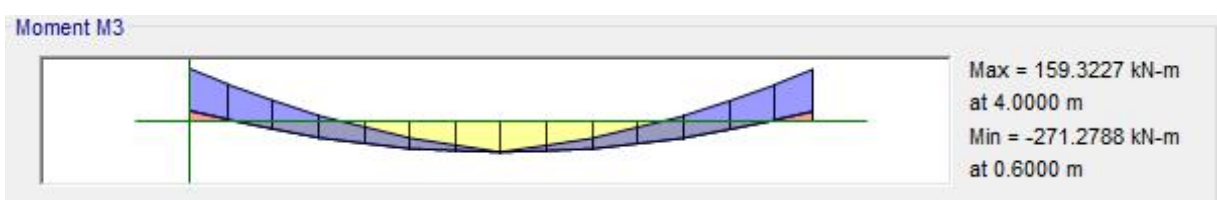

Gambar 12. Diagram Momen Model 2

Berbeda halnya dengan kolom, demand/capacity ratio pada model 2 lebih kecil dibandingkan model 1. Reduksi gaya geser yang dihasilkan dari base isolation menghasilkan demand yang dimiliki model 2 menjadi lebih kecil dibandingkan dengan model 1. Sebelum dilakukan analisis riwayat waktu, demand/capacity ratio pada kedua model diusahakan tidak memiliki perbedaan yang signifikan (perbedaan rasio 0.1-0.2) sehingga optimasi kolom dapat dilakukan. Berdasarkan luas penampang, optimasi yang terjadi pada kolom yang memiliki dimensi $700 \times 1200 \mathrm{~mm}^{2}$ dan $800 \times 1400 \mathrm{~mm}^{2}$ menjadi $600 \times 1000 \mathrm{~mm}^{2}$ dan $700 \times 1200 \mathrm{~mm}^{2}$. Sedangkan, tulangan longitudinal sebesar $25 \%$ dan $24.52 \%$. 


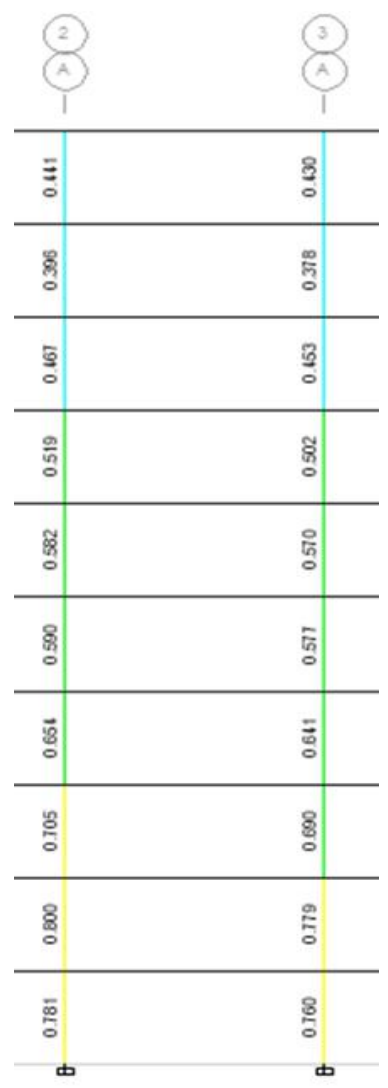

Gambar 13. D/C Ratio Kolom Model 1

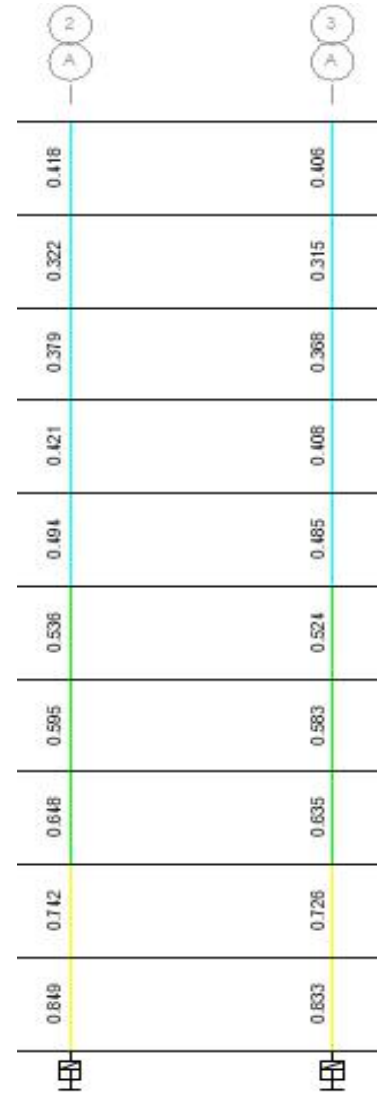

Gambar 14. D/C Ratio Kolom Model 2

Tabel 6. Perbandingan Dimensi Kolom Model 1 dan Model 2

\begin{tabular}{cccc}
\hline \multirow{2}{*}{ Lokasi } & \multicolumn{2}{c}{ Dimensi Kolom $(\mathbf{m m})$} & \multirow{2}{*}{$\begin{array}{c}\text { Optimasi } \\
\text { (\%) }\end{array}$} \\
\cline { 2 - 3 } Fixed Base & Base Isolation & \\
\hline Lantai 6-10 & $700 \times 1200$ & $600 \times 1000$ & 28.57 \\
\hline Lantai 1-5 & $800 \times 1400$ & $700 \times 1200$ & 25.00 \\
\hline
\end{tabular}

Tabel 7. Perbandingan Kebutuhan Tulangan Kolom Model 1 dan Model 2

\begin{tabular}{|c|c|c|c|}
\hline \multirow{2}{*}{ Lokasi } & \multicolumn{2}{|c|}{ Tulangan Longitudinal $\left(\mathrm{mm}^{2}\right)$} & \multirow{2}{*}{$\begin{array}{c}\text { Optimasi } \\
(\%)\end{array}$} \\
\hline & Fixed Base & Base Isolation & \\
\hline Lantai 6-10 & 8496 & 6372 & 25.00 \\
\hline Lantai $1-5$ & 11256 & 8496 & 24.52 \\
\hline
\end{tabular}

\section{Sendi Plastis}

Berdasarkan konsep desain, struktur bangunan tahan gempa harus terbuat dari sistem struktur yang perilakunya daktail. Struktur dengan daktilitas tertentu memungkinkan terjadinya sendi plastis. Semakin banyak sendi plastis yang terjadi, maka semakin banyak pula energi yang diserap oleh struktur. Agar struktur memiliki daktilitas yang tinggi, maka harus direncanakan sendi plastis yang terjadi berada pada balok dan bukan terjadi pada kolom. Dalam analisis riwayat waktu digunakan tiga rekaman gempa yaitu El Centro 1940, Denpasar 1979 dan Flores 1992. Pada model 1, selain terjadi di balok sendi plastis juga terjadi di kolom. 
Berbeda halnya dengan model 2, sendi plastis hanya terjadi di balok. Hal ini membuktikan bahwa base isolation meningkatkan kinerja kolom.

Tabel 8. Terjadinya Sendi Plasti pada Model 1

\begin{tabular}{ccccccc}
\hline \multirow{2}{*}{$\begin{array}{c}\text { Rekaman } \\
\text { Gempa }\end{array}$} & \multicolumn{4}{c}{ Awal } & & \multicolumn{2}{c}{ Akhir } & \\
\cline { 2 - 3 } & \multicolumn{2}{c}{ Periode (detik) } & Lokasi & \multicolumn{2}{c}{ Periode (detik) } & Lokasi \\
\cline { 2 - 3 } \cline { 5 - 6 } & $\mathbf{X}$ & Y & & X & Y & \\
\hline El Centro & 4.6 & 4.6 & Balok & 5.7 & 5.7 & $\begin{array}{c}\text { Balok }+ \\
\text { Kolom }\end{array}$ \\
\hline Denpasar & 7.3 & 7.3 & Balok & 7.5 & 7.5 & $\begin{array}{c}\text { Balok }+ \\
\text { Kolom }\end{array}$ \\
\hline Flores & 39.8 & 39.8 & Balok & 40.9 & 40.8 & $\begin{array}{c}\text { Balok }+ \\
\text { Kolom }\end{array}$ \\
\hline
\end{tabular}

Tabel 9. Terjadinya Sendi Plasti pada Model 2

\begin{tabular}{|c|c|c|c|c|c|c|}
\hline \multirow{4}{*}{$\begin{array}{c}\text { Rekaman } \\
\text { Gempa }\end{array}$} & \multicolumn{6}{|c|}{ Sendi Plastis - Model 2} \\
\hline & \multirow{2}{*}{\multicolumn{2}{|c|}{$\frac{\text { Awal }}{\text { Periode (detik) }}$}} & \multirow{3}{*}{ Lokasi } & \multirow{2}{*}{\multicolumn{2}{|c|}{$\begin{array}{c}\text { Akhir } \\
\text { Periode (detik) }\end{array}$}} & \multirow{3}{*}{ Lokasi } \\
\hline & & & & & & \\
\hline & $\mathbf{X}$ & $\mathbf{Y}$ & & $\mathbf{X}$ & $\mathbf{Y}$ & \\
\hline El Centro & 4.6 & 4.6 & Balok & 5.7 & 4.9 & Balok \\
\hline Denpasar & 11.1 & 11.1 & Balok & 11.3 & 11.3 & Balok \\
\hline Flores & 39.9 & 39.9 & Balok & 41.1 & 41.1 & Balok \\
\hline
\end{tabular}

\section{Tingkat Kinerja Struktur}

Berdasarkan FEMA 356, tingkat kinerja struktur dibagi menjadi Immediate Occupancy (IO), Life Safety (LS) dan Collapse Prevention (CP) yang ditentukan berdasarkan roof drift ratio. Terjadi perbedaan tingkat kinerja struktur pada model 1 dan model 2 yang dianalisis dengan rekaman gempa Flores. Model 1 memiliki tingkat kinerja struktur LS sedangkan model 2 memiliki tingkat kinerja struktur IO.

Tabel 10. Perbandingan Tingkat Kinerja Struktur

\begin{tabular}{|c|c|c|c|c|c|c|c|}
\hline \multirow[t]{2}{*}{$\begin{array}{c}\text { Rekaman } \\
\text { Gempa }\end{array}$} & \multirow[t]{2}{*}{ Model } & \multicolumn{2}{|c|}{$\begin{array}{l}\text { Perpindahan } \\
\text { Maksimum } \\
\quad(\mathbf{m m})\end{array}$} & \multirow{2}{*}{$\begin{array}{l}\text { Tinggi } \\
\text { Gedung } \\
(\mathrm{mm})\end{array}$} & \multicolumn{2}{|c|}{ Rasio } & \multirow{2}{*}{$\begin{array}{l}\text { Tingkat } \\
\text { Kinerja } \\
\text { Struktur }\end{array}$} \\
\hline & & $\mathbf{X}$ & $\mathbf{Y}$ & & $\mathbf{X}$ & $\mathbf{Y}$ & \\
\hline \multirow{2}{*}{ El Centro } & 1 & 131.29 & 133.74 & \multirow{6}{*}{32000} & 0.0041 & 0.0042 & IO \\
\hline & 2 & 63.72 & 66.10 & & 0.0020 & 0.0021 & IO \\
\hline \multirow{2}{*}{ Denpasar } & 1 & 75.66 & 68.10 & & 0.0024 & 0.0021 & IO \\
\hline & 2 & 40.26 & 41.18 & & 0.0013 & 0.0013 & $\mathrm{IO}$ \\
\hline \multirow{2}{*}{ Flores } & 1 & 176.83 & 185.57 & & 0.0055 & 0.0058 & LS \\
\hline & 2 & 137.54 & 144.86 & & 0.0043 & 0.0045 & $\mathrm{IO}$ \\
\hline
\end{tabular}




\section{KESIMPULAN}

Penelitian ini mengkaji dua model gedung yang identik sama secara geometri tetapi memiliki perbedaan pada dasar gedung yaitu penggunaan fixed base dan base isolation. Melalui analisis respons spektrum diperoleh hasil berupa reduksi gaya geser dasar akibat disipasi energi yang dimiliki base isolation sebesar $29.47 \%$ pada arah x dan $29.19 \%$ pada arah y. Selain itu, hasil pengecekan kolom menunjukkan bahwa penggunaan base isolation berdampak pada kekuatan dan kinerja kolom sehingga terjadi optmasi dimensi dan tulangan longitudinal. Besarnya optimasi pada dimensi kolom adalah 25\% (800 x $1400 \mathrm{~mm}^{2}$ menjadi $\left.700 \times 1200 \mathrm{~mm}^{2}\right)$ pada lantai $1-5$ dan $28.57 \%\left(700 \times 1200 \mathrm{~mm}^{2}\right.$ menjadi $\left.600 \times 1000 \mathrm{~mm}^{2}\right)$ pada lantai 6-10. Seiringan dengan hal tersebut, terjadi optimasi kebutuhan tulangan longitudinal sebesar $24.52 \%$ dan $25 \%$. Di sisi lain, penggunaan base isolation meningkatkan kebutuhan tulangan longitudinal pada balok induk sebesar 3.2\%. Hal tersebut dikarenakan kekakuan yang dimiliki base isolation tidak mampu menahan momen lentur pada kolom sehingga terjadi distribusi momen.

Berdasarkan analisis riwayat waktu, kedua model gedung masih dapat beroperasi setelah diuji dengan rekaman gempa El Centro dan Denpasar. Namun, terjadi perbedaan tingkat kinerja struktur dengan pengujian rekaman gempa Flores. Model 2 memiliki tingkat kinerja struktur immediate occupancy, sedangkan model 1 memiliki tingkat kinerja struktur life safety sehingga memerlukan sedikit perbaikan untuk dapat beroperasi kembali ketika gempa yang serupa terjadi. Hal lain yang tentunya menjadi salah satu tinjauan utama adalah sendi plastis. Pada model 2 sendi plastis hanya terjadi pada balok, sedangkan pada model 1 sendi plastis terjadi pada balok dan kolom. Hal tersebut menunjukkan bahwa penggunaan base isolation membantu meningkatkan daktilitas suatu struktur.

Penelitian ini dapat dilanjutkan dengan melakukan perbandingan lead rubber bearing dengan base isolation lainnya (friction pendulum bearing, high damping rubber bearing, rollerand ball bearing atau flat slider bearing) sehingga dapat dijadikan acuan dalam mempertimbangkan penggunaan base isolation yang lebih efektif.

\section{DAFTAR PUSTAKA}

SNI 1726:2012. Standar Nasional Indonesia 1726:2012 Tata Cara Perancanaan Ketahanan Gempa untuk Struktur Bangunan Gedung dan Non Gedung.

SNI 1727:2013. Standar Nasional Indonesia 1727:2013 Beban Minimum untuk Perancangan Bangunan Gedung dan Struktur Lain.

FEMA 356. (2000). Prestandard and Commentary for the Seismic Rehabilitation of Buildings. Federal Emergency Management Agency. Washington, DC.

FEMA 451. (2007). NEHRP Recommended Provisions for New Buildings and Other Structure: Training and Instructional Materials. Federal Emergency Management Agency. Washington, DC.

IBC (2000). International Building Codes. International Code Council. Washington, DC.

Kelly, T.E. (2001). Base Isolation of Structure. Holmes Consulting Group Ltd. Wellington, New Zealand.

Pawirodikromo, W. (2012). Seismologi Teknik \& Rekayasa Kegempaan. Pustaka Pelajar. Yogyakarta.

Ambasta, S., Sahu, D., dan Khare, G.P. (2018). "Analysis of the Base Isolated Building (Lead Plug Bearing) in ETABS". International Research Journal of Engineering and Technology, Vol. 05, No.1.

Somasekharaiah, H.M., Dharmesh, Er. N., dan Ghouse, M. (2016). "A Comparative Study on RC Frame Structure Considering Lead Rubber Bearing and Triple Friction Pendulum Bearing". International Journal of Innovative Research in Science, Engineering and Technology. Vol 5. No. 8. 
Ismail, F. A. (2012), "Pengaruh Penggunaan Seismic Base Isolation System Terhadap Respons Struktur Hotel Ibis Padang". Jurnal Teknik Sipil, Vol. 8, No. 1.

Patel, Y., dan Kumar, P.P. (2017). "Comparision of Fixed Base and Base Isolation Reinforced Concrete Structure for Seismic Response". International Journal of Advance Engineering and Research Development, Vol. 4. ISSN: 2348-4470.

Ridho, A.S., Welsi, Chandra, Y., dan Jalalul, S.A. (2017). "Studi Komparasi Base Shear pada Gedung Menggunakan Base Isolator Dan Non Base Isolator”. Teras Jurnal, Vol. 7, No. 4.

Pratama, F., Setiya, A.B., dan Wibowo. (2014). "Evaluasi Kinerja Struktur Gedung 10 Lantai dengan Analisis Time History pada Tinjauan Drift dan Displacement Menggunakan Software ETABS". E-Jurnal Matriks Teknik Sipil, Vol.2, No. 3.

Soemitro, R.A.A. \& Suprayitno, H. (2018). "Pemikiran Awal tentang Konsep Dasar Manajemen Aset Fasilitas". Jurnal Manajemen Aset Infrastruktur \& Fasilitas, Vol. 2, Suplemen 1, Juni 2018, Hal. : 1-13.

Suprayitno, H. \& Soemitro, R.A.A. (2018). "Preliminary Reflexion on Basic Principle of Infrastructure Asset Management". Jurnal Manajemen Aset Infrastruktur \& Fasilitas, Vol. 2, No. 1, Maret 2018, Hal. : 1-9.

UU 28/02. Undang-Undang Republik Indonesia Nomor 22 Tahun 2002 tentang Bangunan Gedung. 
(e)ISSN 2615-1847 (p)ISSN 2615-1839

Jurnal Manajemen Aset Infrastruktur \& Fasilitas - Vol. 3, No. 2, September 2019 